\title{
PENGARUH GROUP INVESTIGATION TERHADAP MINAT BACA MAHASISWA: PERHATIAN, PERSEPSI POSITIF, PERASAAN SENANG
}

\author{
Eva amalia', Ali Mustadi ${ }^{2}$ \\ Surel: evaamalia.2017@student.uny.ac.id
}

\begin{abstract}
This study aims to determine the effect of the group investigation model on students' interest in reading (attention, positive perception, and feeling happy). Research subjects 78 semester 4 students of PGSD UST. This study uses quasiexperimental methods (quasi experiment) with the design of two groups, namely the experimental class and the control class. The results showed the average reading interest of the experimental class on the pre-test 23,084 and on the post-test 26,205 so that there was influence. In the average control class the results of the 23,025 pre-test and post-test were still assumed to be 23,538, there was no increase as much as the experimental class. Based on the data it can be concluded that the group investigation model influences students' reading interest, especially positive perceptions and feelings of pleasure.
\end{abstract}

\section{Keywords: Cooperative Learning, Group Investigation}

\begin{abstract}
ABSTRAK
Penelitian ini bertujuan mengetahui pengaruh model group investigation terhadap minat baca (perhatian, persepsi positif, dan perasaan senang) mahasiswa. Subjek penelitian 78 mahasiswa semester 4 PGSD UST. Penelitian ini menggunakan metode eksperimen semu (quasi experiment) dengan desain dua kelompok, yaitu kelas eksperimen dan kelas kontrol. Hasil penelitian menunjukkan perolehan rata-rata minat baca kelas eksperimen pada pre-test 23.084 dan pada post-test 26.205 sehingga terdapat pengaruh. Pada kelas kontrol rata-rata hasil pre-test 23.025 dan post-test tetap diangka 23.538 , tidak terdapat kenaikan sebanyak kelas eksperimen. Berdasarkan data dapat disimpulkan bahwa model group investigation berpengaruh terhadap minat baca mahasiswa terutama persepsi positif dan perasaan senang.
\end{abstract}

Kata Kunci: Cooperative Learning, Group Investigation

PENDAHULUAN

Membaca

memiliki

kandungan unsur yang rumit serta melibatkan banyak hal seperti melafalkan tulisan, aktivitas visual, berpikir, psikolinguistik, dan metakognitif (Rahim, 2008:2). Membaca memiliki berbagai manfaat yang sangat penting dalam kehidupan. Membaca memberikan wawasan yang luas serta memberikan imajinasi

${ }^{12}$ Universitas Negeri Yogyakarta 
kepada pembaca. Membaca dapat menjadi landasan untuk seseorang mempelajari berbagai pengetahuan serta menerapkannya dalam kehidupan sehari- hari. Tanpa membaca orang akan tertinggal dan tidak mengetahui informasi yang ada dan sedang berkembang. Berbagai arti penting membaca mengharuskan orang untuk menyukai membaca demi kebaikan hidupnya. Membaca tidak dapat dilepaskan dengan minat baca. Minat baca merupakan keinginan seseorang untuk membaca. Seseorang yang tidak pernah membaca akan mengalami kesulitan dalam membaca (Rahim, 2005:3). Minat baca sangat perlu untuk dikembangkan. Minat baca merupakan tingkatan teratas yang harus dimunculkan dalam kegiatan membaca.

$\begin{array}{rrr}\text { Kondisi } & \text { minat } & \text { baca di } \\ \text { Indonesia } & \text { sendiri } & \text { sangat }\end{array}$
memperihatinkan. Belum banyak orang yang sadar akan pentingnya membaca. Membaca masih dianggap sebagai hobi, membaca seperti aktivitas rigid yang hanya boleh terjadi di sekolah. Fasilitas berupa buku bacaan juga sangat jarang disediakan di lingkungan maupun di rumah sekalipun. Berdasarkan kenyataan tersebut lebih dipastikan dengan hasil studi Most Littered Nation In the World yang dilakukan oleh Central Connecticut State University pada Maret 2016, menunjukan Indonesia menduduki peringkat minat baca ke 60 dari 61 negara. Indonesia berada pada posisi di bawah Thailand, dan satu tingkat di atas Botswana (http://oecd.org/pisa).

Berdasarkan hasil dari PISA 2016 diperoleh gambar pemetaan Reading Indonesia yang menunjukan warna merah. Warna merah tersebut mengindikasikan minat baca masih rendah.

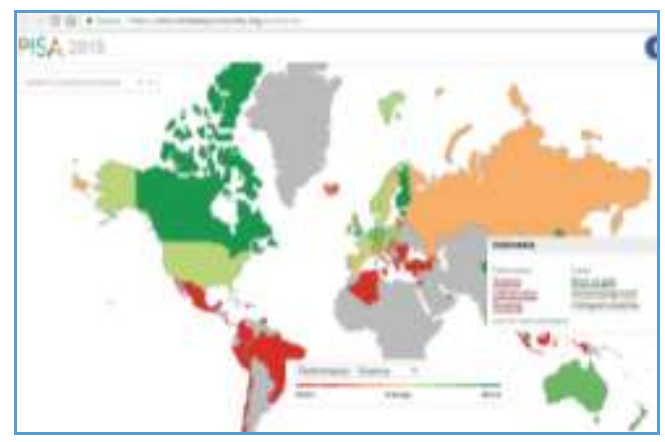

Gambar 1. Persebaran Kemampuan Membaca

Aspek minat baca meliputi sikap, perasaan keterlibatan atau psikomotorik. Sehingga aspek minat baca adalah scbagai berikut 1) sikap positif tehadap kegiatan membaca berupa perasaan suka atau setuju terhadap membaca 2) perasaan suka kepada aktivitas membaca 3) ketertarikan terhadap kegiatan membaca 4) keinginan mendapatkan bacaan baik meminjam atau memimbeli 5) ketertarikan terhadap aktivitas membaca tanpa adanya paksaan. Berdasarkan penjelasan di atas maka minat membaca merupakan suatu usaha seseorang dalam kegiatan membaca. Orang yang mempunyai minat baca yang kuat akan diwujudkannya dalam kesediaannya untuk mendapat bahan bacaan dan kemudian membacanya atas kesadarannya 
sendiri. Beberapa aspek minat baca tersebut adalah 1) aspek kognitif meliputi perhatian terhadap aktivitas membaca, persepsi positif terhadap kegiatan membaca 2) aspek afektif berupa perasaan senang terhadap kegiatan membaca, dan menjadikan kegiatan membaca sebagai aktivitns yang penting dan berharga, 3) aspek psikomotorik meliputi keterlibatan dalam kegiatan membaca melipti intensitas dan kualitas dalam membaca (Hurlock, 2009: 116118). Aspek-aspek tersebut saling berkaitan dan menjadi komponen inti terhadap penilaian siswa terhadap minat baca yang dilakukan. Sehingga aspek minat membaca yang diteliti dalam penelitian ini adalah perhatian, persepsi positif, perasaan senang, penting. Penelitian ini hanya terfokus pada ketiga indicator karena agar lebih terfokus dan terarah.

Salah satu upaya yang dapat dilakukan untuk menaikkan minat baca mahasiswa adalah penggunaan model pembelajaran. Model yang dipilih adalah group investigation karena dalam langkahnya terdapat proses investigasi yang membutuhkan kemampuan mengorek informasi mendalam salah satunya menggunakan membaca. Untuk melakukan investigasi diperlukan minat baca yang tinggi. Sehingga pada proses ini diharapkan dapat berpengaruh pada aspek -aspek minat baca mahasiswa.

\section{METODE PENELITIAN}

Metode yang digunakan dalam penelitian ini adalah quasi experiment (penelitian semu) tipe nonequivalent control group design. Populasi penelitian adalah seluruh mahasiswa semester 4 PGSD UST dalam Mata Kuliah Sastra Anak dengan jumlah 78 mahasiswa yang terbagi menjadi dua kelas. Kelas 4I PGSD UST terdiri dari 39 mahasiswa dan kelas 4H PGSD UST terdiri dari 39 mahasiswa. Kelas 4 H PGSD UST sebagai kelas kontrol dan kelas 4I PGSD UST sebagai kelas eksperimen. Kedua kelas memiliki kemampuan akademik yang hampir sama dan diajar oleh dosen yang sama sehingga mempermudah peneliti untuk melanjutkan materi kuliah sastra anak

Instrumen yang digunakan dalam penelitian ini berupa angket, skala minat baca pada Mata Kuliah Sastra Anak menggunakan angket pretes postes mahasiswa yang terdiri dari 10 butir soal pernyataan. Pernyataan disusun berdasarkan indikator minat baca mahasiswa pada Mata Kuliah Sastra Anak. Teknik analisis data yang digunakan yaitu statistik deskriptif dengan membandingkan rata -rata. Analisis data dilakukan dengan melihat ratarata skor minat baca antara kelas eksperimen dan kelas kontrol. Hasil perbandingan nilai rata-rata tersebut digunakan untuk menentukan hipotesis diterima atau ditolak. Apabila rata-rata skor aktivitas belajar 
pada kelompok eksperimen lebih tinggi daripada rata-rata skor minat baca mahasiswa pada kelompok kontrol maka hipotesis diterima. Namun, apabila hasilnya sebaliknya maka hipotesis yang diajukan ditolak.

\section{HASIL DAN PEMBAHASAN}

Penelitian ini dilakukan untuk mengetahui pengaruh model group investigation terhadap minat baca mahasiswa semester empat PGSD UST. Data yang diperlukan dalam penelitian ini adalah data minat baca mahasiswa sebelum dan sesudah diberikan perlakuan. Pada penelitian ini, baik kelas eksperimen maupun kelas kontrol diberi angket minat baca mahasiswa sebagai pre-test. Setelah diberi pre-test, kelas eksperimen diberi perlakuan dengan menggunakan model group investigation, sedangkan kelompok kontrol tidak diberikan perlakuan apapun. Setelah itu, baik kelas eskperimen maupun kelas kontrol diberi post-test dengan menyebarkan angket minat baca mahasiswa.

Tabel 1. Kenaikan Skor Pretes Postes

\begin{tabular}{lll}
\hline Hasil & $\begin{array}{l}\text { Kelas } \\
\text { Kontrol }\end{array}$ & $\begin{array}{l}\text { Kelas } \\
\text { Eksperimen }\end{array}$ \\
\hline Skor Pretes & 23.025 & 23.084 \\
\hline Skor Postes & 23.538 & 26.205 \\
\hline $\begin{array}{l}\text { Kenaikan } \\
\text { skor }\end{array}$ & 0.513 & 3.121 \\
\hline
\end{tabular}

Pada table di atas diperoleh hasil bahwa kelas $4 \mathrm{H}$ sebagai kelas control memiliki hasil skor rata -rata pretes 23.025 dan postes 23.538 terjadi kenaikan skor 0.513. Pada kelas eksperimen 4I skor rata -rata pretes hampir sama dengan kelas control atau kelas $4 \mathrm{H}$ yaitu 23.084. Setelah menerapkan group investigation terjadi peningkatan sebanyak 3.121 dari 23.084 menjadi 26.205.

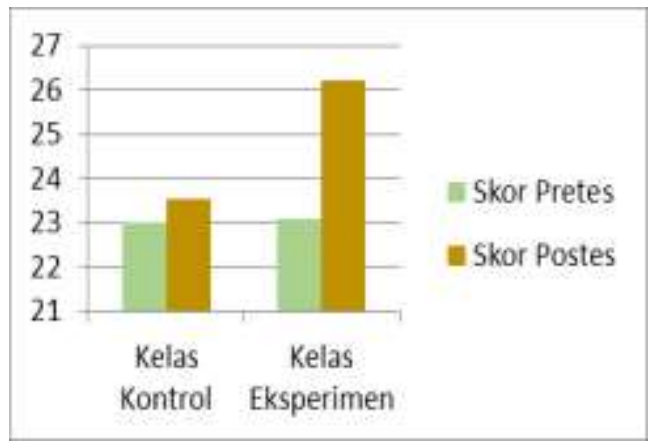

Gambar 1. Kenaikan Skor

Apabila diperbandingkan kenaikan skor lebih besar terjadi pada kelas eksperimen yaitu sebanyak 3.121. Kenaikan skor antara kelas control dan kelas eksperimen terpaut sekitar 2.5 poin. Sehingga dapat disimpulkan bahwa group investigation berpengaruh pada minat baca siswa.

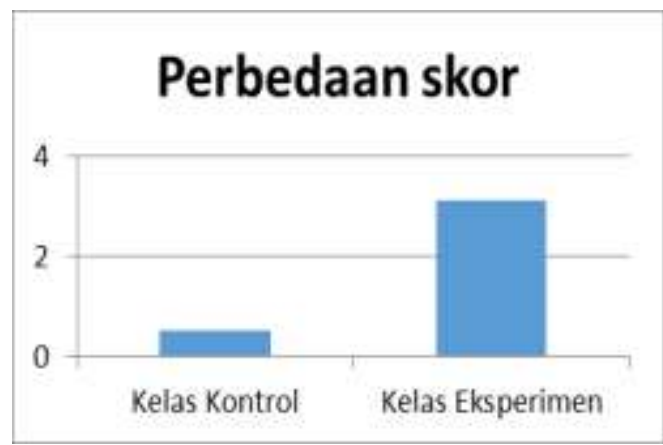

Gambar 2 Perbedaan Skor

Selain hasil keseluruhan dibawah ini merupakan hasil peningkatan perindikator minat baca: 
Berdasarkan hasil penelitian hasil rata - rata skor perhatian terhadap bacaan terjadi penurunan skor dari 2.282 menjadi 2.179. Penurunan skor terjadi sekitar 0.103. Indikator perhatian terhadap bacaan dalam angket terletak dalam butir pertanyaan pertama hingga ketiga. Didalamnya terdapat butir yang menyatakan mahasiswa berkonsentrasi terhadap kegiatan membaca, mahasiswa telah membaca materi sebelum perkuliahan, dan konsisten dalam membaca.

Tabel.2 Hasil Rata-rata skor Perhatian

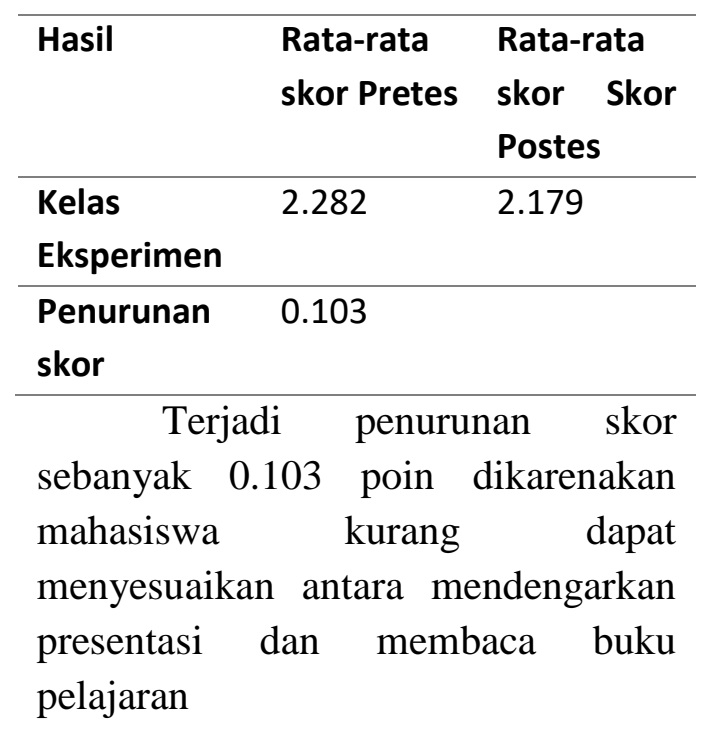

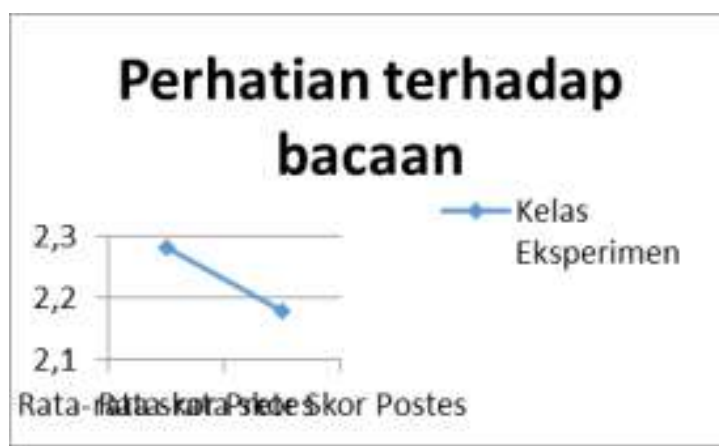

Gambar 3.Skor indicator perhatian terhadap bacaan.Indikator yang kedua adalah persepsi positif. Berdasarkan hasil penelitian diperoleh data sebagai berikut:

Tabel 3. Indikator persepsi positif

\begin{tabular}{lll}
\hline Hasil & $\begin{array}{l}\text { Rata-rata } \\
\text { skor Pretes }\end{array}$ & $\begin{array}{l}\text { Rata-rata } \\
\text { skor Skor } \\
\text { Postes }\end{array}$ \\
\hline $\begin{array}{l}\text { Kelas } \\
\text { Eksperimen }\end{array}$ & 2.583 & 2.685 \\
\hline $\begin{array}{l}\text { Kenaikan } \\
\text { skor }\end{array}$ & 0.102 & \\
\hline
\end{tabular}

Terjadi kenaikan skor kelas eksperimen dalam pretes dan postes. Pada pretes mendapatkan skor 2.583 dan pada postes mendapat skor 2.685. Terjadi kenaikan skor rata -rata sebanyak 0.102. Persepsi positif terdapat pada pertanyaan butir ke 4,5,6,7 yang dinyatakan dengan pernyataan persepsi positif yaitu penasaran dan ingin membaca, merasa membaca sangat penting, selalu ingin tahu dan melampiaskan dengan membaca.

\section{Skor indikator Persepsi Positif}

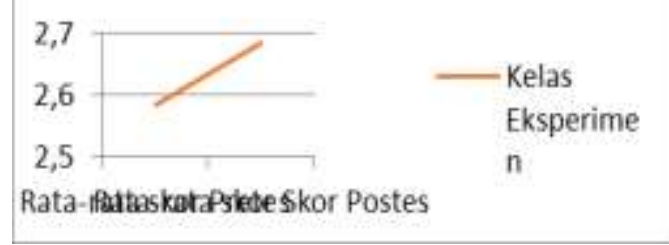

Gambar 4. Skor Persepsi Positif

Setelah pembelajaran dengan GI mahasiswa memiliki persepsi positif yang meningkat sebanyak 0.102 skor. 
Selain persepsi positif setelah dilakukan penelitian didapatkan hasil minat baca indicator perasaan senang meningkat.Pada angket perasaan senang terletak pada butir soal 8,9,10. Pernyataan dalam angket adalah menguji apakah mahasiswa senang dengan membaca, apakah ada rasa kantuk dan bosan dengan membaca, dan apakah mahasiswa antusias saat membaca. Berdasarkan angket tersebut diperoleh hasil rata- rata skor pretes kelas eksperimen sebanyak 2.811 sedang kan skor postes kelas eksperimen menjadi 2.974. Berdasarkan hasil pretes dan postes dapat disimpulkan bahwa indicator perasaan senang mahasiswa saat membaca mengalami kenaikan sebanyak 0.163 poin. Hal ini menandakan bahwa group investigation dapat meningkatkan perasaan senang.

Tabel4. Kenaikan skor perasaan senang

\begin{tabular}{lll}
\hline Hasil & $\begin{array}{l}\text { Rata-rata } \\
\text { skor Pretes }\end{array}$ & $\begin{array}{l}\text { Rata-rata } \\
\text { skor Skor } \\
\text { Postes }\end{array}$ \\
\hline $\begin{array}{l}\text { Kelas } \\
\text { Eksperimen }\end{array}$ & 2.811 & 2.974 \\
\hline $\begin{array}{l}\text { Kenaikan } \\
\text { skor }\end{array}$ & 0.163 & \\
\hline
\end{tabular}

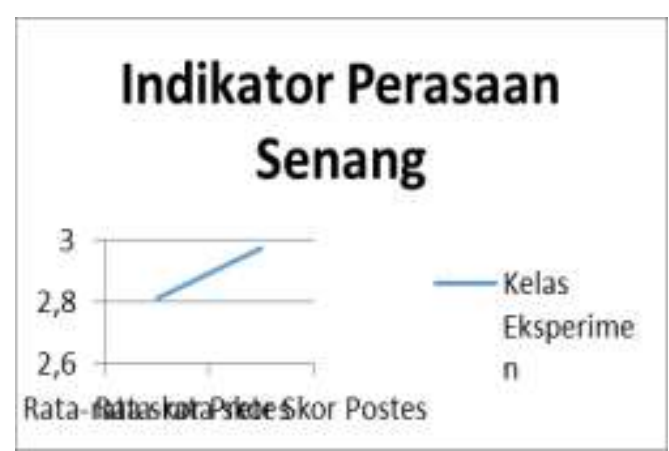

Gambar.5 Kenaikan skor Perasaan Senang

\section{Pembahasan}

Model Group investigation diterapkan pada kelas 4I PGSD UST untuk meningkatkan minat baca pada kelas eksperimen. Setelah diberikan perlakuan (treatment) menggunakan model Group investigation, terjadi peningkatan pada perasaan senang dan persepsi positif. Hal ini dibuktikan ketika proses pembelajaran berlangsung mahasiswa membuka buku dan membaca dan mengkroscek materi dari apa yang dibaca.

Selain itu dibuktikan juga
dengan table kenaikan skor hasil
penelitian. Terjadi kenaikan skor
pretes dan postes kelas eksperimen
3.121. Angka ini mengindikasikan
terjadi peningkatan minat baca siswa
menggunakan model group
investigation. Selain itu dibandingkan dengan kelas control, terdapat selisih 2.5 poin kenaikan antara kelas control dan kelas eksperimen. Kenaikan pretes dan postes kelas control juga hanya sekitar 0.5 poin. Hal ini menjadi dasar bahwa group investigation dapat berpengaruh pada 
minat baca berdasarkan dari hasil perbandingan skor rata-rata pretes dan postes pada masing - masing kelas. Group Investigation dapat berpengaruh terhadap minat baca karena di dalam langkah group investigation terdapat langkah proses investigasi.Sebagai bagian dari investigasi para siswa harus mencari berbagai sumber di dalam maupun diluar kelas. Sumber tersebut diantaranya berasal dari buku ( Slavin, 2015 : 216). Pada saat mencari informasi saat investigasi dalam buku mau tidak mau mahasiswa dituntut untuk membaca sehingga terjadi peningkatan minat baca.

Pada indikator persepsi positif terjadi peningkatan skor dari 2.583 menjadi 2.685. Hal ini menyiratkan bahwa group investigation dapat meningkatkan persepsi positif. Peningkatan juga terjadi pada perasaan senang. Hasil pretes yang semula 2.811 menjadi menjadi 2.974 . Perasaan senang pada membaca menjadi meningkat.

\section{SIMPULAN}

Mengacu pada rumusan masalah dan hasil penelitian, maka dapat disimpulkan bahwa model group investigation berpengaruh terhadap minat baca mahasiswa khusunya persepsi positif dan perasaan senang. Hal tersebut dapat ditunjukkan dengan rata-rata skor minat baca mahasiswa kelas eksperimen yang menggunakan model group investigation lebih baik daripada kelas kontrol yang tidak menggunakan model group investigation. Pembelajaran sebaiknya menggunakan model pembelajaran yang tepat sesuai dengan karakteristik mahasiswa. Dalam penelitian ini, peneliti memberi saran bahwa perkuliahan dengan menggunakan model group investigation dapat dijadikan sebagai salah satu alternatif model pembelajaran yang diterapkan bagi mahasiswa dalam Mata Kuliah Sastra Anak, dapat pula dikembangkan pada mata kuliah lain dengan harapan dapat meningkatkan minat baca dan prestasi belajar. Melalui pembelajaran model group investigation, minat baca mahasiswa dapat meningkat. Minat baca mahasiswa yang meningkat tersebut menyebabkan mahasiswa mendapatkan pembelajaran yang lebih..

\section{DAFTAR RUJUKAN}

Hurlock, Elizabeth. (2009). Perkembangan Anak.

(Terjemahn Med Meitasari Tjandrasa).

Jakarta: Erlangga.

PISA. (2016). Pemetaan kemampuan Reading di Indonesia. http://oecd.org diakses 5 Maret 2018

Rahim, Farida. (2008). Pengajaran membaca di sekolah dasar (edisi kedua). Jakarta: Bumi Aksara. 
Rahim, Farida. (2011). Pengajaran Membaca di Sekolah Dasar. Jakarta: Bumi Aksara.

Rude Robert \& Oehlkers, William. (1984). Helping Students with Reading Problem. London: Pratice-Hall International.

Samadi, F. \& Mohammadi, F.A. (2013). The interaction between Iranian EFL learner's interest in reading comprehension topics and their reading comprehension ability. European Online Journal of Natural and Social.
Schunk, Pintrich \& Meece. (2012). Motivasi dalam Pendidikan: Teori, Penelitian dan Aplikasi, (Terjemahan Ellys Tjo). Jakarta: Indeks.

Schunk, Dale. (2012) Learning Theories, (Terjemahan Eva Hamdiah dan Rahmat Fajar). Yogyakarta: Pustaka Pelajar.

Slavin. (2005). Cooperative learning. London: Alymand Bacondi web Elementary School Journal. 